\title{
Egyptian Middle Kingdom copper: analysis of a crucible from Buhen in the Petrie Museum
}

\author{
Christopher J Davey ${ }^{(1,2)}$, Brunella Santarelli( ${ }^{(3)}$ and Thilo Rehren ${ }^{(3,4)}$ \\ (1) University of Melbourne, Parkville Vic 3052, Australia \\ (2) Australian Institute of Archaeology, La Trobe University, Vic 3086, Australia \\ (3) The Cyprus Institute, 20 Konstantinou Kavafi Street, 2121, Aglantzia, Nicosia, Cyprus \\ (4) UCL Institute of Archaeology, 31-34 Gordon Square, London, UK
}

\begin{abstract}
The study of a well-preserved crucible fragment from the Middle Kingdom Egyptian fortress in Buhen in lower Nubia revealed the unexpected presence of numerous prills of very arsenic- and nickel-rich coper alloy in what looks like a smelting slag. Based on optical and scanning electron microscopy on a polished section, this paper discusses the potential metallurgical process that was carried out in this Middle Kingdom Egyptian type of crucible. Strongly reducing conditions preserved in the sample taken from near the low-sitting spout of the vessel indicate that it was likely used for smelting a very rich secondary copper-arsenic ore, rather than for the more oxidising refining of raw copper, or simple casting of copper-arsenic alloy. However, the evidence is not unambiguous, and these alternative interpretations are also discussed, considering the chronology and geographical context of the fortress near a known copper deposit in what was then the southern border of pharaonic Egypt.
\end{abstract}

Keywords: Crucible, metallurgy, Middle Kingdom, Buhen, copper-arsenic alloy, microanalysis

\section{Introduction}

The smelting and working of metals, in particular copper, is a defining feature of post-Neolithic societies. However, this innovation did not occur everywhere at the same time or in the same fashion, and much of the variability of the earliest metallurgy was driven as much by intrinsic cultural as it was by external environmental conditions, within the overriding constraints imposed by thermodynamic requirements. Crucibles were used in a wide range of pyrometallurgical processes and an even wider range of shapes and design solutions (Bayley and Rehren 2007). Accordingly, they are primary cultural objects, no more so than in the Early Dynastic Period, Old and Middle Kingdoms of Egypt where a crucible profile was adopted by the hieroglyphic writing system to denote 'metalworker' and 'copper'. These crucibles and associated texts are depicted in Old Kingdom tomb scenes, such as the Tomb of Mereruka, where they are employed in the casting of copper, a process which according to Davey (2018) probably included refining. One such crucible was recently found in a 2nd Dynasty (c 2,800 BCE) context at Elkab in Upper Egypt, published with a detailed description and discussion in Claes et al. (2019), but the type is not restricted to ancient Egypt. These crucibles have sometimes been referred to as 'Mereruka-style' and in profile they are the same as those found at the Isin-Larsa Period site of Tell edh-Dhiba'i in Baghdad (Davey 1983). A distinctive feature of these crucibles is that they have a low-sitting opening or spout near their bottom beneath a 'bridge' where the upper part of the crucible wall continues uninterrupted, and therefore will not retain a liquid when held in an upright position, in stark contrast to most other crucibles employed in 
Egypt and elsewhere (Figure 1: 1-3). Instead, during use the frontal opening would have been at least partially closed with a temporary clay cover. Alternatively, some of these crucibles may have been used for melting in a reclined position (Davey 2009), with casting achieved through a rocking or tilting motion bringing the spout forward and down. Like almost all early crucibles they were fired internally, with air provided by blow pipes (Davey 2012: 101).

A significant number of crucibles and crucible fragments from the First Intermediate Period and Middle Kingdom have been discovered in areas of Egyptian hegemony (Figure 1: 4-11). They are like the Elkab-Mereruka style in that they have a hole in the side, but they have a bowl-shaped base so that they can retain a liquid when upright (Claes et al 2019: Fig. 10). It has been suggested that these vessels developed from the earlier Elkab-Mereruka style of crucible and that they were also used for melting metal (Davey 2009: 45-46). This paper calls these suggestions into question. It presents results of our ongoing research into one of these Middle Kingdom crucible fragments, which came from Buhen in Nubia. It reveals that the assumed purpose of the crucible is far from certain and highlights the discovery potential that such analyses offer, as well as the ambiguity of results that limits a conclusive interpretation.
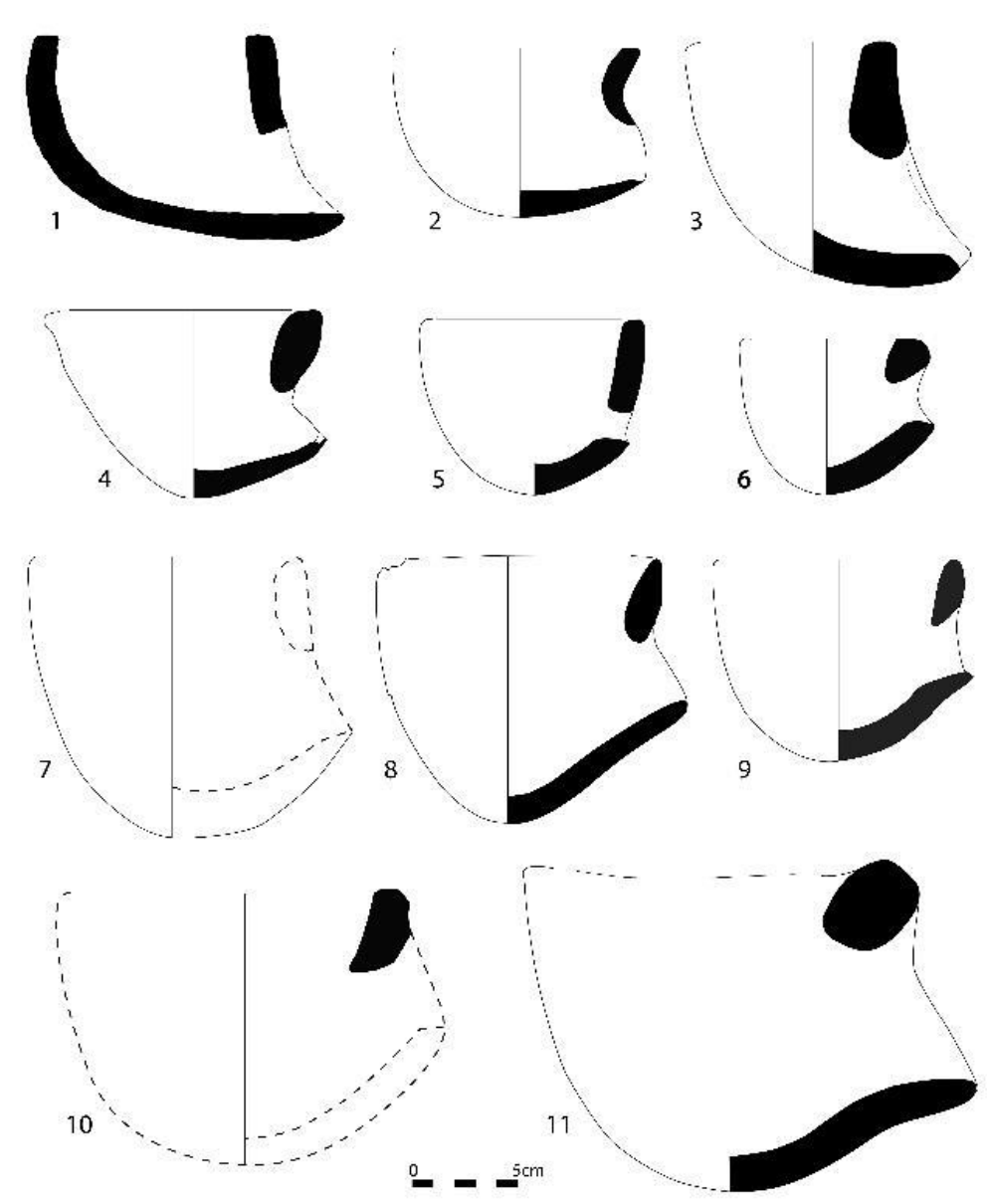

Figure 1: Crucibles from areas of Egyptian Hegemony and Tell edh-Dhiba'i. Early Dynastic Period: 1 Elkab. Old Kingdom: 2 Buhen. Mesopotamia: 3 Tell edh-Dhiba'i. First Intermediate Period and Middle Kingdom: 4 Buhen; 5 Byblos; 6 Ayn Soukhna; 7 Buhen, UC 21748; 8 Badari; 9 Ayn Soukhna; 10 Ayn Soukhna; 11 Serâbît el-Khâdim (after Claes et al. 2019: Fig. 10). 


\subsection{The site and previous work}

The ancient city of Buhen was located immediately below the second cataract on the west bank of the Nile in the Sudan and near the border with Egypt (Figure 2). It was often the southern frontier of the ancient Egyptian state. Prior to its inundation in 1964, it was excavated by the University of Pennsylvania's Eckley B. Coxe Expedition in 1909-10 under the direction of David Randall-Maclver and Leonard Woolley (Randall-Maclver and Woolley, 1911), and then, beginning in 1957, by Walter

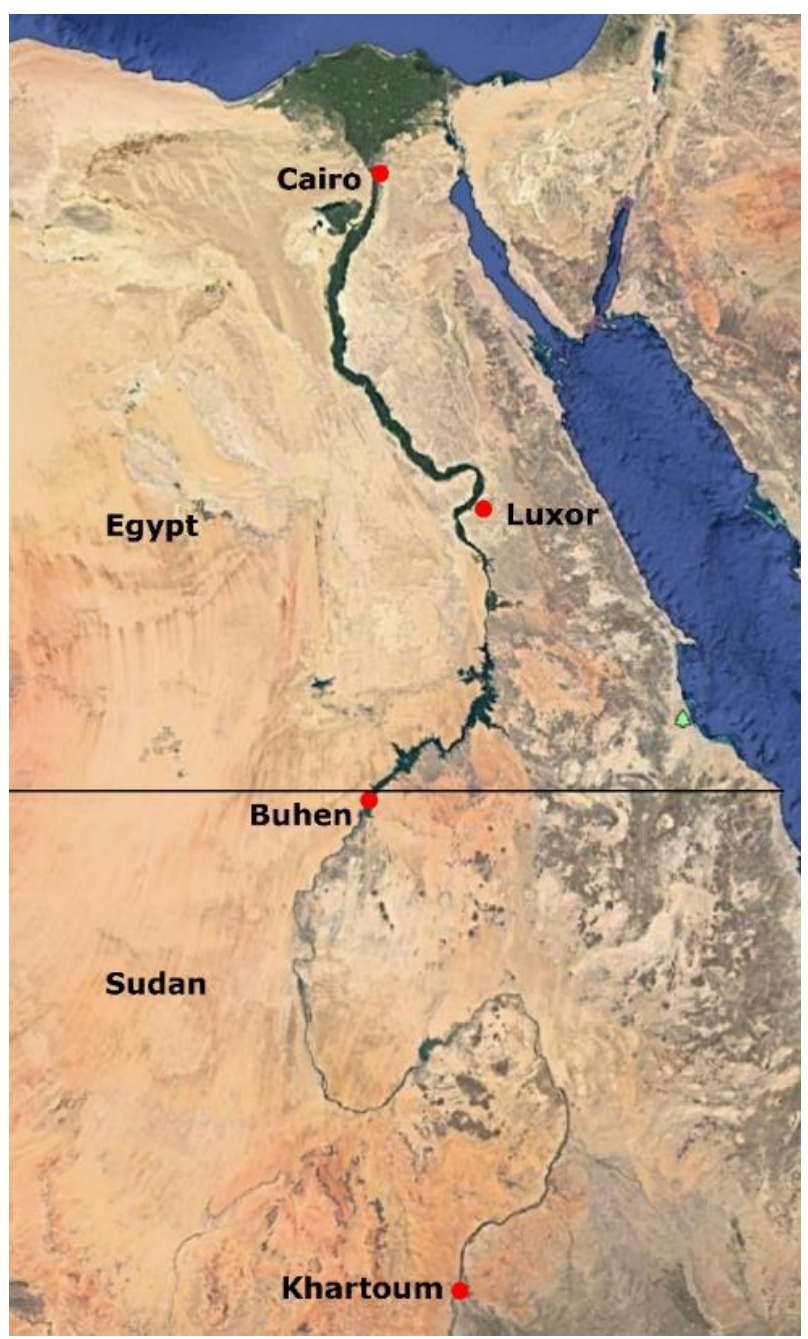

Figure 2: Map showing location of Buhen.

Emery found what he claimed was an Old Kingdom copper 'factory', making the site important to Egyptologists researching metal working (Emery, 1963: 116-120). He collected samples including a fragment of copper ore, some of the smelted copper metal, copper-smelting slag, pieces of a crucible and a small artefact made from the copper. These were exported to the Petrie Museum of Egyptian Archaeology at University College London, and analysed at the Royal School of Mines, 
London by El Gayar and Jones (El Gayar and Jones, 1989a). Attempts to locate this material have been unsuccessful.

A piece of ore weighing $150 \mathrm{gm}$ was studied under a microscope, with XRD and chemical analysis. The ore was found to be mostly finely dispersed quartz (c $44 \mathrm{wt} \%$ ) and malachite with a significant amount of atacamite, a copper chloride. There were no sulphide minerals. Based on the distribution of the atacamite on the surface and in cracks of the analysed sampled, El Gayar and Jones proposed that the atacamite formed when the malachite reacted with chlorine ions during the occasional inundation of the site by the Nile (El Gayar and Jones, 1989a: 33). Other elements detected by atomic absorption analysis included $2.3 \mathrm{wt} \%$ zinc, $1.4 \mathrm{wt} \%$ calcium, $0.48 \mathrm{wt} \%$ lead, and $0.1 \mathrm{wt} \%$ silver, but remarkably little iron (0.04 wt\%); no data for arsenic is given in their analyses. The Electron Probe Micro-Analyser detected an average of $0.18 \mathrm{wt} \%$ of gold in parts of the ore prepared for optical microscopy (El Gayar and Jones 1989a: 35). A similar amount of gold was found in a cross section of a corroded copper prill from the site (El Gayar and Jones 1989b: 17); other elements, detected by AAS, include $0.5 \mathrm{wt} \%$ iron, $0.2 \mathrm{wt} \%$ lead, and only $0.05 \mathrm{wt} \%$ zinc; again, no arsenic values are given. El Gayar and Jones proposed that crucible smelting was practiced at the site and that the ore may have been associated with the known gold deposits not far from Buhen on the west bank of the Nile (El Gayar and Jones, 1989b).

The recent publication of the Old Kingdom town site by O'Connor does not support Emery's interpretations, although he accepts some of El Gayar's analyses (2014: 203-228, 337; El Gayar \& Jones 1989a). He seems to be comfortable that the site was used for mineral processing, but not for pyro-metallurgical treatment. Emery's furnace structures have the appearance of pottery kilns. The crucible referred to by Giddy as UC 20064 (Giddy 1987: 227 n. 9; 337 n. 67) is unknown to O'Connor, and the crucible published by Emery and Kirwan (1935: 62, pl. 14 xxii, 286/C2-C1) is not mentioned. Nicholson agrees that some of Emery's metallurgical features are questionable (Arnold et al., 1993: 109). El Gayar does report on the analyses of slag and vitrified furnace lining, which point to pyrometallurgical processes (EI Gayar \& Jones 1989a). Unfortunately, the archaeological publication of the Old Kingdom town site was not able to incorporate the sample analyses in its interpretations.

The Middle Kingdom Fortress site was published in 1979 (Emery et al., 1979). The fortress, dated to the Twelfth Dynasty and probably constructed around 1860 BC, yielded crucibles, two from the surface and one from the West Inner Fortifications that are designated pottery Type 188 (Emery et al. 1979: 176, pl. 19). These crucibles were reported to be left at the site with much of the Buhen pottery where they cannot now be investigated (pers. comm. H.S. Smith). Two other Buhen crucibles are in the Petrie Museum at University College London, UC 21423 (Figure 1: 4) and UC 21748 (Figure 1: 7). Crucible UC 21423 is not listed in the Index and Distribution List of Emery (1979) but is almost identical to the published drawing of pottery Type 188, which itself is very similar to the crucible that appeared in the 1935 publication of the survey in the Buhen area (Emery \& Kirwan 1935: 62, pl. 14 xxii; Emery et al. 1979: 176, pl. 19).

\subsection{The analysed crucible fragment UC 21748}

Crucible fragment UC 21748 was published with a description and drawing and is listed as number 741 in the Fortress of Buhen Index and Distribution list (Emery et al. 1979: 95, 122, pl. 43). It is typical of other Egyptian crucibles of the period, few of which are available for analytical study. Its 
outer surface is buff coloured and shows no sign of heat exposure. The dark grey fabric, indicative of being fired under reducing conditions, has numerous straw shaped vesicles up to $5 \mathrm{~mm}$ long, likely due to intentional tempering of the clay used to build the crucible, and what appear to be natural quartz inclusions. All evidence of high temperatures is on the internal surface, where there is much vitrification indicating that the crucible had been heated internally. Opposite the low-sitting spout there is a lighter coloured section that is not vitrified and may indicate that the crucible was ventilated by two blowpipes obliquely, rather than directly, through the front opening. There is no clear 'waterline', but corroded copper is evident to a level a little above the invert of the spout and there are areas below this where the thickness of the vitrified material would indicate a small deposition of dross in addition to the bloating of the ceramic.

A sample of the crucible fabric including the inner vitrified surface was taken from the location shown in Figure 3, an area where internal operational temperatures would have been at their highest; the section does not include the outer surface but ends in the central or core area of the ceramic. The analyses of the sample undertaken at the Cyprus Institute (Cyl) aimed to investigate the fabric of this typical Middle Kingdom crucible and to identify the metallurgical process conducted within the vessel: ore smelting, or copper refining, melting or alloying.

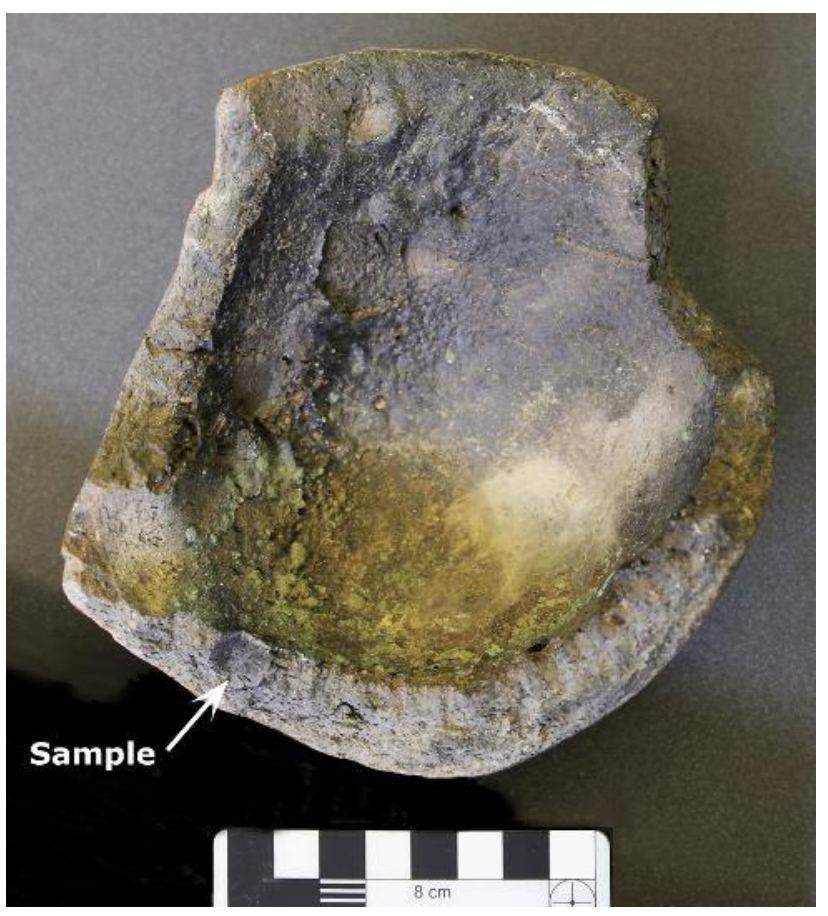

Figure 3: Photograph showing sample location of Middle Kingdom crucible from Buhen (UC 21748). The remnants of the spout are to the left. For drawing, see Fig. 1: 7.

\section{Analytical Methods}

A small section of crucible fragment UC 21748 was removed by curatorial staff at the Petrie Museum and prepared as a polished cross section by Andreas Ludwig at the Deutsches Bergbau-Museum in 
Bochum before being sent to Cyl for analysis. In order to provide an ideal flat surface even in materials with different hardnesses, such as quartz-containing low-fired or porous ceramics, the polishing step at the DBM includes lapping the mounted block on a lead-based plate, which results in widespread contamination of porous samples with metallic lead particles trapped in pores and cracks.

The crucible section was first studied in reflected light using a Zeiss Axio Imager optical microscope and images collected with the Zeiss Zen 2 Core software. SEM-EDS analysis was performed with a Zeiss EVO 15 SEM equipped with an Oxford Instruments Ultim Max Energy-Dispersive Spectrometer with a 65 SDD detector. EDS analysis was carried out in high vacuum, at $20 \mathrm{kV}, 1 \mathrm{nA}$, with a $30 \mu \mathrm{m}$ aperture and at $8.5 \mathrm{~mm}$ WD. During the quantification process, the Aztec software was set to ignore lead for all analysis points due to the known contamination of the sample with this element from the sample preparation procedure. Bulk EDS analyses were performed over areas with average dimensions of $100 \mu \mathrm{m} \times 100 \mu \mathrm{m}$; as many area analyses as possible were collected in the different zones of the crucible, resulting in 5 to 10 analyses per zone. The size of the areas and their quantity was in part determined by the lead contamination, as care was taken to avoid analyzing areas with visible high lead concentrations.

The detection limit for the system is lower than approximately $0.5 \mathrm{wt} \%$ for most of the oxides analyzed; when concentrations are above this threshold, the analytical results have an error margin lower than $10 \%$ (and in most cases lower than $5 \%$ ). For concentrations ranging between $0.5 \mathrm{wt} \%$ and $0.1 \mathrm{wt} \%$ the results are increasingly less reliable as concentrations decrease. The precision is equally high, with coefficient of variation generally below $5 \%$ for oxides with concentrations above $0.5 \mathrm{wt} \%$.

\section{Results}

Microscopic examination of the crucible section identified four distinct zones. The majority of the section consists of the normal fired ceramic body, from the core towards the outer edge of the crucible, with occasional quartz grains and small iron oxide inclusions, and evidence of chaff temper throughout (Figure 4a). The major components are silica and alumina, with iron oxide and lime (Table 1). Above this zone, towards the interior surface of the crucible, there is a bloated layer of heavily vitrified ceramic with large porosity, followed by a thinner, dense zone of completely fused ceramic fabric.

The composition of this fused inner layer is fairly similar to the rest of the ceramic, with an increased lime content likely due to the fuel ash from the charcoal. This lime acts as a flux for the ceramic and leads to the observed fused appearance in the high-temperature region. This sequential texture seen in the crucible is typical for internally heated vessels, and the composition of the ceramic is consistent with published compositions of Nile siliceous ceramics (Hope et al., 1981; Schoer and Rehren, 2007). 

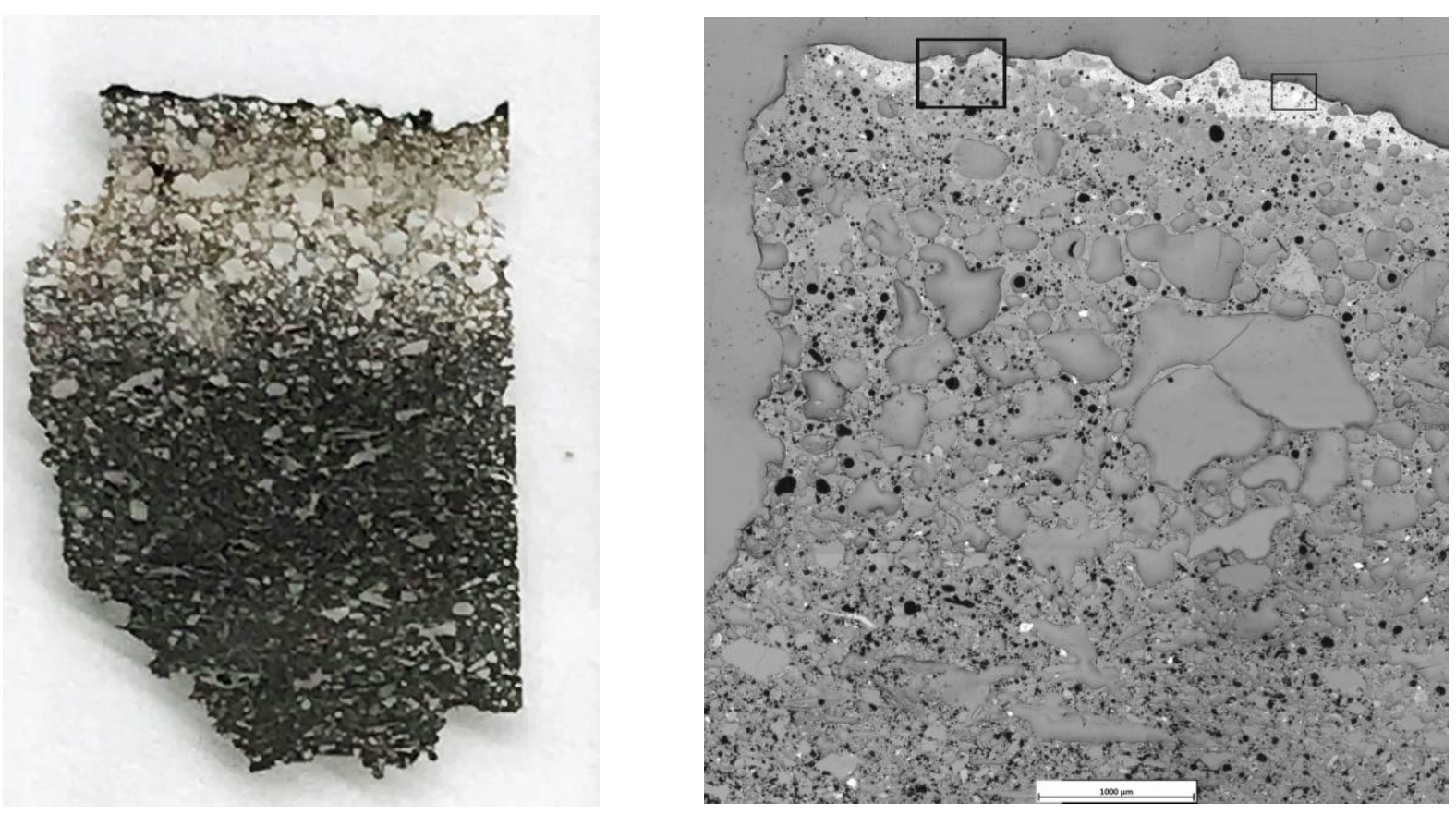

Figure 4a: Polished thin section of the sample, showing the bloated region near the inside surface (upper part) and the central part of the ceramic with numerous chaff temper voids (lower half); the outer surface is not included in the sample. Height of section is $1 \mathrm{~cm}$. Figure $4 \mathrm{~b}$ : Detail of the upper left part of the polished block sample, showing the slag-rich inner surface layer (light grey, top), the bloated section with large porosity (central part of image) and the less altered ceramic with porosity from organic temper and normal vitrification in the lower part of the image. Montage of separate OM images. The area shown represents about half of the total thickness of the sample. The black frames show areas of Fig. 5 (left) and Fig. 6 (right), respectively. Sample UC 21748, width of picture c $5 \mathrm{~mm}$.

Table 1: Oxide wt\% bulk composition of ceramic and slag layer. SEM-EDS area analyses, data normalized to 100 $w t \%$ to compensate for porosity. nd = not detected, i.e. present below c 0.1 wt\%.

\begin{tabular}{l|ccccccccccccccc}
\hline & $\mathrm{Na}_{2} \mathrm{O}$ & $\mathrm{MgO}$ & $\mathrm{Al}_{2} \mathrm{O}_{3}$ & $\mathrm{SiO}_{2}$ & $\mathrm{P}_{2} \mathrm{O}_{5}$ & $\mathrm{SO}_{3}$ & $\mathrm{Cl}$ & $\mathrm{K}_{2} \mathrm{O}$ & $\mathrm{CaO}$ & $\mathrm{TiO}_{2}$ & $\mathrm{FeO}$ & $\mathrm{CoO}$ & $\mathrm{NiO}$ & $\mathrm{CuO}^{\mathrm{As}_{2}}$ & $\mathrm{O}_{3}$ \\
\hline $\begin{array}{l}\text { Ceramic } \\
\text { Body }\end{array}$ & 1.3 & 2.6 & 17.4 & 56.3 & 0.9 & 0.1 & 0.4 & 2.7 & 4.7 & 2.3 & 11.4 & nd & nd & nd & nd \\
$\begin{array}{l}\text { Ceramic } \\
\text { Fused }\end{array}$ & 1.5 & 3.2 & 17.2 & 56.5 & 0.7 & $\mathrm{nd}$ & 0.1 & 2.6 & 6.9 & 1.5 & 9.8 & $\mathrm{nd}$ & $\mathrm{nd}$ & $\mathrm{nd}$ & $\mathrm{nd}$ \\
$\begin{array}{l}\text { Crucible } \\
\text { Slag }\end{array}$ & 0.5 & 2.1 & 6.7 & 30.0 & 0.7 & $\mathrm{nd}$ & 0.2 & 0.7 & 9.4 & 0.9 & 43.6 & 0.8 & 0.2 & 3.8 & 0.3 \\
\hline
\end{tabular}

On the interior surface of the crucible there is a thin layer ( $100-300 \mu \mathrm{m}$ thick) of crucible slag covering the bloated ceramic zone (Fig. 4b), formed from a combination of molten ceramic fluxed with fuel ash, and remains of the charge. This thin slag layer consists of iron oxide crystals and metallic prills in a glassy siliceous matrix (Figure 5). Bulk compositional analyses of this layer shows it to be dominated by iron oxide with silica as the next prominent oxide, and several weight percent lime, alumina, copper oxide and magnesia (Table 1). The bulk analyses of the slag layer avoided the largest copper prills as well as any visible porosity (to avoid any trapped contaminant lead). The crystal phases in the slag layer include silicates (pyroxenes and fayalite), spinels (magnetite and hercynite), and delafossite (found only along the surface of the slag layer). 


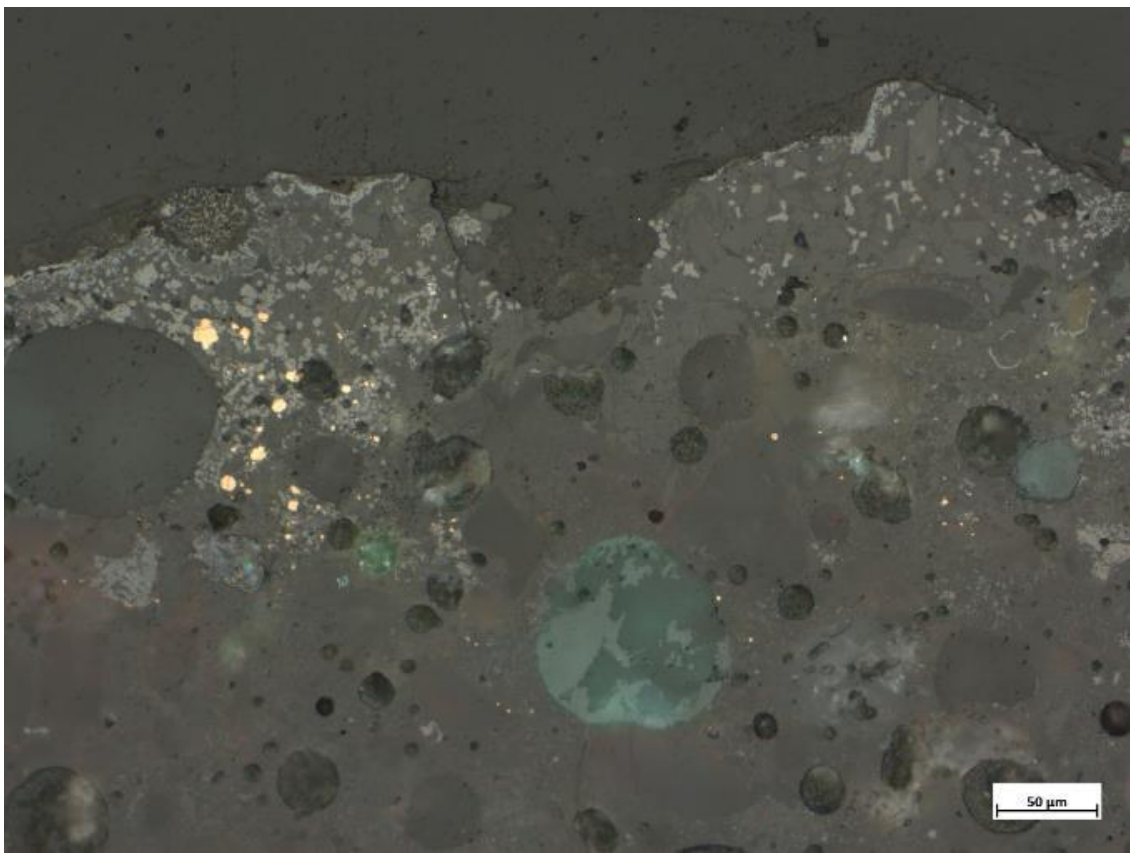

Figure 5: Plane polarized reflected light image of fused ceramic fabric with crucible slag layer (top), showing copper prills (bright yellow, left), free iron oxides (mid-grey crystals) and fayalite in a glassy matrix (darker grey shades). Green areas are porosity in the bloated ceramic filled with secondary copper corrosion products.

To estimate the enrichment of oxides in the slag compared to the ceramics, the ratios of silica, lime and iron oxide to alumina were calculated (Table 2), assuming that the only source for alumina is in the ceramic contribution to the slag formation. In contrast, silica, lime and iron oxide in the slag can all come partly from the molten ceramic, but also from the crucible charge. The massive increase of iron oxide in the slag compared to the ceramic is obvious; accordingly, the silica content in the slag appears much lower than in the ceramic. The ratios, however, show that the slag layer is in fact enriched in all three components, including silica, when compared to the ceramic fabric, with the apparent decrease of silica due to the 'dilution' of ceramic material through the addition of large quantities of iron oxide. Relative to the original alumina content, however, silica is still enriched by about $40 \%$ of its initial content, indicating that there was also silica in the crucible charge.

Table 2: Ratios of oxides for slag and ceramic. Note the increase in the slag in all three oxides relative to alumina, with iron oxide increasing ten-fold, lime five-fold, and silica by more than $1 / 3$ of the original content.

\begin{tabular}{l|ccc}
\hline & $\mathrm{SiO}_{2} / \mathrm{Al}_{2} \mathrm{O}_{3}$ & $\mathrm{CaO} / \mathrm{Al}_{2} \mathrm{O}_{3}$ & $\mathrm{FeO} / \mathrm{Al}_{2} \mathrm{O}_{3}$ \\
\hline Ceramic Body & 3.2 & 0.27 & 0.65 \\
Crucible Slag & 4.5 & 1.4 & 6.5 \\
\hline
\end{tabular}
few microns to the largest having a diameter of $60 \mu \mathrm{m}$ (Figure 6). 


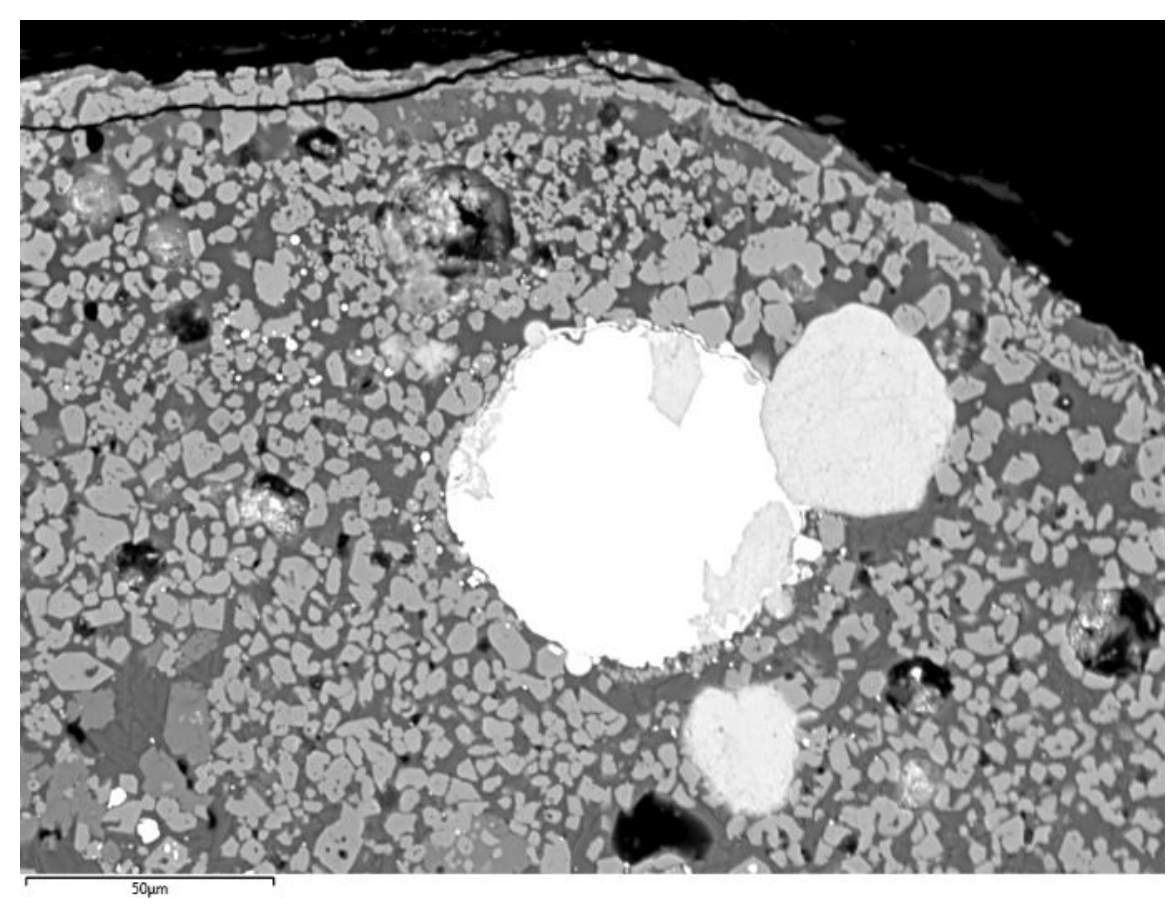

Figure 6: BSE image of slag layer, showing large copper prill (bright, $60 \mu$ m diameter) surrounded by iron oxide phases (mostly hercynitic magnetite; only the thin layer at the surface is composed of delafossite). The light grey phases visible in and next to the copper prill were identified as a copper-chlorine corrosion product, also visible in the green areas in Figure 5.

Approximately 30 prills in the slag layer were analyzed. All are composed predominantly of copper, with an average composition including several weight percent each of iron, nickel and arsenic, suggesting a Cu-Fe-As-Ni quaternary alloy (Table 3). There is significant variability in the metal content of individual prills, but even the lowest levels of the alloying elements rarely go below 1 $w t \%$. Particularly remarkable is the high level of arsenic which covers a range from 2-22 wt\%, averaging at more than $10 \mathrm{wt} \%$. No lead content was detected in these metallic prills, nor in the surrounding vitrified ceramic, indicating no lead in the alloy. Thus, the expected original lead content in the rest of the crucible would also be correspondingly low.

Table 3: Element wt\% of copper prills in slag layer, from 33 individual prills. Data is normalized to $100 w t \%$

\begin{tabular}{l|cccc}
\hline & Fe & Ni & Cu & As \\
\hline Average & 3.8 & 3.3 & 81.9 & 11.0 \\
Min & 0.7 & 0.7 & 63.9 & 2.6 \\
Max & 7.1 & 10.5 & 95.0 & 22.4 \\
\hline
\end{tabular}

\section{Discussion}

Optical microscopy and SEM-EDS analyses were used to study the texture of the slag, to identify the phases present, and their spatial associations, in order to allow us to assess the metallurgical function of this crucible. The main research question was whether the crucible was used to smelt 
copper ore to extract copper metal, or whether it was used to refine pre-existing copper metal, or to simply melt copper or a copper alloy for casting. The data collected suggests that this crucible was used for the former, the smelting of copper ores under partially reducing conditions; however, other interpretations are also feasible.

\subsection{Smelting?}

The first indicator for a smelting process is the compositional difference between the ceramic fabric and the slag layer, particularly the increased contents in iron oxide, lime and silica (Tables 1, 2). This difference can only be attributed to the presence of materials associated with the crucible charge other than copper metal, i.e. should come from the ore, intentionally added flux, or the fuel ash. Of the three oxides found to be increased relative to the alumina from the ceramic it is primarily the silica which most strongly suggests that the crucible was used for smelting. It is noteworthy that a piece of malachite found at the Old Kingdom town of Buhen was previously analyzed and found to contain significant quartz (El Gayar and Jones, 1989a) with low iron content (El Gayar and Jones, 1989b). Another possible source for silica is fuel ash, particularly if straw or similar silica-rich agricultural waste was used as fuel; unfortunately, distinguishing between ore-derived and ashderived silica is difficult to do on its own.

The high amounts of iron oxides in the slag layer (over $40 \mathrm{wt} \%$ in the bulk composition, as opposed to just over $11 \mathrm{wt} \%$ in the ceramic) could either stem from added flux, as proposed by El Gayar and Jones $(1989 a, b)$ as a necessity to smelt the quartz-rich malachite ore, or could originate from a selffluxing malachite ore naturally rich in iron hydroxide, as known from Timna and Feinan (Hauptmann 2007) and elsewhere (e.g., in Chalcolithic Bulgaria, Rehren et al. 2016); both scenarios would be indicative of a smelting process. Alternatively, it could be the result of an intentional or accidental refining of 'raw' copper metal during remelting, selectively burning out the small but still significant quantities of iron metal typically present within freshly-smelted copper (Craddock 2000: 154). It is unlikely, however, to have formed during the simple remelting of previously worked or alloyed copper, since such metal would not normally have an elevated iron content to produce an iron-rich crucible slag. The identity of the newly-formed phases in the slag further indicate reducing conditions consistent with copper smelting; the fayalite crystals are blocky and equi-axial, suggesting a slow cooling of the melt. While phases such as magnetite and delafossite are usually associated with the more oxidizing conditions prevalent during melting processes, they have been found in early copper smelting slags (Müller et al., 2004). Particularly magnetite is the dominant iron oxide phase in copper-reducing conditions (Hauptmann, 2007). The location of the more oxidized delafossite along the outer surface of the slag (facing the interior space of the crucible) indicates a slightly more oxidizing environment on the surface of the slag towards the end of the process when the slag layer was exposed to ambient air, immediately freezing as well as oxidizing superficially. Overall, it is very likely that the smelting environment inside the crucible was not at equilibrium throughout the entire working volume, and there were areas of differing conditions based on thermal gradients, amount of reducing agent and other factors (Rademakers and Rehren 2016; Rademakers et al. 2018 Gordion).

The significant content of iron and arsenic in the metallic prills further indicates a smelting process under reducing conditions, when these elements are quite soluble in molten copper and thus would easily become incorporated in the copper. Under more oxidizing conditions, at least some of the 
arsenic and iron could be expected to be oxidized and to 'burn out' of the copper, leading to textures where magnetite 'skins' surround arsenical copper prills, such as those seen in Iron Age copper slag in Arabia (Liu et al. 2015: Fig. 5). There is significant variability in the arsenic content of the prills, from $2 \mathrm{wt} \%$ up to $22 \mathrm{wt} \%$, but no prill was found without arsenic. This variability is a common feature of prill compositions, and likely due to local heterogeneity of the charge. The absence of any cuprite in the slag layer further confirms the reducing conditions of the process.

An important consideration when discussing the nature of the metallurgical operation carried out in this crucible concerns the rather limited amount of slag present, both in the section examined, and more broadly in the crucible overall. If indeed this crucible served for copper smelting from ore, then this would have been a very pure ore, resulting in a very small amount of slag relative to the presumably much larger amount of copper produced. The uncertainty of the modus operandi of the crucible makes it impossible to reliably determine the 'effective volume' of liquid copper that this vessel could have held. In an upright position the crucible will retian about $80 \mathrm{ml}$ of liquid. It it was tilted backward 45 degrees, this may be increased to $150 \mathrm{ml}$. However, it is unlikely that the crucible was tilted as this would hinder ventilation with blowpipes; in any case, if more volume was required the crucible would have been made with a deeper bowl. The weight of liquid copper was therefore about 0.6 to $0.7 \mathrm{~kg}$, before overflowing. This, of course, is the maximum possible amount the crucible could have held, and does not imply that it actually would have been completely filled; however, even half of this volume would still have required two orders of magnitude more ore than the amount of slag preserved in the vessel, estimated to be probably less than ten grams (see Figs. 3 and 4 , above). The ore would therefore have to be $99 \%$ malachite and similar minerals leading to a virtually 'slag-less' smelting; a far cry from the Old Kingdom ore sample analysed by El Gayar and Jones (1989a) which contained 45\% quartz.

The small amount of slag present in the crucible therefore points against an interpretation as smelting slag; instead, it could represent the residue left behind from a re-melting operation of preexisting metal or alloy. In this scenario, the increased silica content in the slag could be explained as having derived from the fuel ash, which can reach silica concentrations of tens of percent (e.g., Pierce et al. 1998; Monti et al. 2008), while the increased iron oxide content could originate from the partial oxidation of the iron content in the metal charge. Assuming a metal charge of $500 \mathrm{~g}$ based on the volume estimate given above, and the measured average iron content in the prills of $3.8 \mathrm{wt} \%$, indicates that the charge would have included nearly $20 \mathrm{~g}$ of metallic iron; only a small proportion of this would have been needed to provide all the iron oxide for $5 \mathrm{~g}$ of iron-rich slag. Rademakers and Rehren (2016) and Rademakers et al. (2018) discuss in much detail the information potential and the very significant limitations particularly of crucible analyses based on single samples; these limitations prevent us from an unequivocal interpretation of the evidence in hand.

\subsection{The arsenic content}

The presence of such high arsenic concentrations in the copper prills was unexpected and does not match the composition of the malachite or metal reported from the earlier layers of the site (EI Gayar and Jones 1989a, b - but note that they did not report data for arsenic). Arsenical copper is common in Middle Kingdom artefacts from Egypt, but these contain rarely, if ever, elevated nickel concentrations reaching the level observed here. On the other hand, artefacts with elevated nickel and arsenic contents in copper are well-known from the Middle East (Pernicka 1990: 88), where this 
particular composition occurs from Maadi in lower Egypt to Anatolia and the lower Euphrates. Such an arsenic-nickel alloy is not, however, known from artefacts in Egypt south of Cairo, making this observation highly unusual. Both arsenic and nickel could have entered the metal either as part of the original copper ore, as all three elements often occur together, or as an intentionally added artificial material known as speiss, an iron arsenide which can also include nickel, and which has been systematically produced and widely traded across the Middle East from at least the Early Bronze Age onward (Rehren et al. 2012). However, at this stage of our research and with a single sample analysed from one of only two extant crucibles from Buhen, it is impossible to pursue this further. Significantly, the addition of speiss would add iron as well as arsenic to the alloy, with the iron likely to be oxidized during the process while the arsenic remains predominantly in the copper, at least under sufficiently reducing conditions. Thus, the occurrence of large amounts of free iron oxide in the crucible slag next to arsenical copper prills would be consistent with the addition of speiss as an alloying material to metallic copper. However, the amount of iron that would have been added to the charge as speiss exceeds by far the amount present in the thin slag film coating the inside of the crucible, even allowing for the still-substantial iron content of the metal prills. As in the previous alternative scenario (see above), the increased amounts of silica observed in the slag would most likely derive from the fuel ash.

\subsection{Smelting crucible}

The balance of the argument makes us believe that the crucible served to smelt arsenical copper from a very pure ore, raising the question of the type of ore smelted. The identity of the ore smelted in UC 21748 is unknown, but based on the total absence of any sulfidic phase (i.e. matte) in the slag coupled with previous archaeological evidence for ores found at Buhen (El Gayar and Jones, 1989a), we suggest it was a copper carbonate, likely malachite, intergrown with any of the secondary nickel arsenic minerals such as annabergite or olivenite. The malachite ore found at the Old Kingdom town of Buhen had nearly $0.2 \mathrm{wt} \%$ of gold, which makes it quite chemically distinct. During smelting the gold would be incorporated into the copper metal, and since no gold content was found in any of the metallic prills in our Middle Kingdom crucible, it indicates that in later periods malachite ores with different chemical signatures were used. The slag has a significant cobalt content (almost $1 \mathrm{wt} \%$ ), which most likely was introduced as part of the charge (associated with the nickel-bearing copper ore). The combination of iron, cobalt and nickel could be related to the geological provenience of the smelted ore, and a copper source with similar elemental profile has been identified based on work done at Pi-Ramesse (Rademakers et al., 2018a). Since only one arsenic-rich copper ore source is known in Egypt (Rademakers et al., 2018b), the co-smelting of intentionally mixed arsenic- and copper minerals remains a valid possibility, too.

\section{Conclusions}

On balance, the crucible was likely used for smelting a complex secondary copper ore, with significant amounts of arsenic, nickel and some cobalt minerals, and an excess of iron oxide relative to the silica / quartz content of the ore; the overall rather small amount of slag preserved in the crucible indicates that the ore would have been rather pure, with little slag-forming gangue. Alternatively, the crucible could have been used for alloying copper with nickeliferous iron-rich 
speiss as an arsenic source, but based on the large quantity of iron that would have come with the arsenic as part of the speiss this would have led to the formation of a much larger amount of iron oxide and crucible slag. Similarly, the refining of raw copper to reduce its iron content would not increase the silica content in the crucible slag, nor is it consistent with the reducing conditions indicated by the presence of fayalite and the absence of any copper oxide. However, the increase of silica in the slag could have come from the fuel used within the crucible, while the strongly reducing conditions seen here may not necessarily be representative of the conditions in the crucible at large. In fact, the overall very limited amount of slag present here could be seen as an indication for refining of raw copper, and only further analyses on more and different samples from a range of such vessels might be able to resolve this question. In any case, the results presented have shown again the potential of such minimally-invasive research to generate new and unexpected information, and the unique composition of the metal in the crucible should serve as a motivation for further research on the material from MK Buhen. A first step could be done by hhXRF for initial non-invasive analyses to test for presence of similar compositions in finds potentially related to the crucible UC 21748, and of similar analyses on other such crucibles elsewhere.

Aside from the possible smelting role of the crucible from Buhen within the specific setting of the MK fortress, the conclusion that this type of crucible could have been used for smelting has further implications for trade, because they have not often been found adjacent to copper mines. It is normally assumed that after the Chalcolithic, copper was predominantly traded as a metal, but it may also have been traded as a mineral, at least on a small scale. This technological interpretation needs to be considered when discussing Buhen style crucibles elsewhere at places such as Wadi Serâbît el-Khâdim and Ayn Soukhna. Finally, it needs to be recognised that there is no reason why such crucibles could not have also been used for melting, refining, alloying and casting of copper, but it would appear that at MK Buhen, small-scale copper smelting was carried out in a crucible.

\section{Acknowledgements}

The UCL Petrie Museum of Egyptian Archaeology is gratefully acknowledged for facilitating the study of the crucible collection and for allowing a sample to be taken from the Buhen crucible fragment, and the Conservation Department of the UCL Institute of Archaeology for taking the sample. Frederik Rademakers generously offered suggestions based on his experience with material from elsewhere in Egypt. Andreas Ludwig at the Deutsches Bergbau-Museum in Bochum is thanked for preparing the polished sections. Anonymous peer review comments further helped us to strengthen the argument; any remaining shortcomings are ours.

\section{Bibliography}

Abdl El-Raziq, M., Castel, G., Tallet, P. Fluzin, Ph. 2011. 'Ayn Soukhna II: les ateliers métallurgiques du Moyen Empire. FIFAO 66, Cairo.

Arnold, D., Bourriau, J., Nordström, H.-Å., 1993. An introduction to Ancient Egyptian pottery. Von Zabern, Mainz am Rhein. 
Bayley, J. and Rehren, Th. 2007. Towards a functional and typological classification of crucibles. In: S. LaNiece, D. Hook and P.T. Craddock (Eds) Metals and Mines - Studies in Archaeometallurgy, 4655.

Claes, W., Davey, Chr.J., Hendrickx, S., 2019. An Early Dynastic Crucible from the Settlement of Elkab (Upper Egypt). Journal of Egyptian Archaeology 105, 29-42.

Craddock, P.T. 2000: From hearth to furnace: evidences for the earliest metal smelting technologies in the Eastern Mediterranean. Paléorient 26, 151-165.

Davey, Chr.J. 1983. The Metal Workers' Tools from Tell edh Dhiba'i. Bulletin of the Institute of Archaeology, University of London, 20, 169-85.

Davey, Chr.J. 2009. A metalworking servant statue from the Oriental Institute, University of Chicago. Bulletin of the Australian Centre for Egyptology 20, 37-46.

Davey, Chr.J. 2012. Old Kingdom metallurgy in Memphite tomb images. In: L. Evans ed. Ancient Memphis: Enduring is the Perfection, Proceedings of the International Conference held at Macquarie University, Sydney, 14-15 August 2008, Peeters: Leuven, 85-108.

Davey, Chr.J. 2018. Early Bronze Age refining of copper, in E. Ben-Yosef ed. Mining for Ancient Copper: Essays in Memory of Professor Beno Rothenberg, Tel Aviv: Institute of Archaeology of Tel Aviv University, 495-503.

El Gayar, E.S., Jones, M.P., 1989a. A Possible Source of Copper Ore Fragments Found at the Old Kingdom Town of Buhen. Journal of Egyptian Archaeology 75, 31-40.

El Gayar, E.S., Jones, M.P., 1989b. Old Kingdom copper smelting artifacts from Buhen in Upper Egypt. Historical Metallurgy 23, 16-24.

Emery, W.B., 1963. Preliminary Report on the Excavation at Buhen. Kush 11, Egypt Exploration Society.

Emery, W.B., Kirwan, L.P. 1935. The Excavations and Survey between Wadi es-Sebua and Adindan 1929-1931. Government Press, Cairo.

Emery, W.B., Smith, H.S., Millard, A., 1979. The Fortress of Buhen: The Archaeological Report. Egypt Exploration Society, London.

Giddy, L. 1987. Egyptian Oases: Bahariya, Dakhla, Farafra, and Kharga During Pharaonic Times. Aris and Phillips.

Hauptmann, A., 2007. The Archaeometallurgy of Copper: Evidence from Faynan, Jordan. Springer, Berlin.

Hope, C.A., Blauer, M., Riederer, J., 1981. Recent analysis of 18th Dynasty pottery, in: Arnold, D. (Ed.), Studien zur Altägyptischen Keramik. von Zabern, 139-166.

Liu Siran, Rehren, Th., Pernicka, E. and Hausleiter, A. 2015: Copper processing in the oases of northwest Arabia: technology, alloys and provenance. Journal of Archaeological Science 53, 492503.

Monti, A., Di Virgilio, N. and Venturi, G. 2008. Mineral composition and ash content of six major energy crops. Biomass and Bioenergy 32, 216-223.

Müller, R., Rehren, Th., Rovira, S., 2004. Almizaraque and the early copper metallurgy of Southeast Spain: New data. Mitteilungen des Deutschen Archäologischen Instituts. Abteilung Madrid 45, 3356.

O'Connor, D. 2014. The Old Kingdom Town of Buhen. Egypt Exploration Society, London.

Pernicka, E. 1990. Gewinnung und Verbreitung der Metalle in prähistorischer Zeit. Jahrbuch des Römisch-Germanischen Zentralmuseums Mainz 37, 21-129.

Pierce, C., Adams, K. and Stewart, J.D. 1998. Determining the fuel constituents of ancient hearth ash via ICP-AES analysis. Journal of Archaeological Science 25, 493-503. 
Rademakers, F. and Rehren, Th. 2016: Seeing the forest for the trees: Assessing technological variability in ancient metallurgical crucible assemblages. Journal of Archaeological Science: Reports 7, 588-596.

Rademakers, F.W., Rehren, Th., Pusch, E.B., 2018a. Bronze production in Pi-Ramesse: alloying technology and material use, in: Ben-Yosef, E. (Ed.), Mining for Ancient Copper: Essays in Memory of Professor Beno Rothenberg. Institute of Archaeology of Tel Aviv, Tel Aviv, 503-525.

Rademakers, F., Rehren, Th. and Voigt, M. 2018. Bronze metallurgy in the Late Phrygian settlement of Gordion, Turkey. Archaeological and Anthropological Sciences 10, 1645-1672.

Rademakers, F.W., Verly, G., Delvaux, L., Degryse, P., 2018b. Copper for the afterlife in Predynastic to Old Kingdom Egypt: Provenance characterization by chemical and lead isotope analysis (RMAH collection, Belgium). Journal of Archaeological Science 96, 175-190.

Randall-Maclver, D., Woolley, L., 1911. Buhen. The University Museum, University of Pennsylvania, Philadelphia.

Rehren, Th., Boscher, L., Pernicka, E. 2012. Large scale smelting of speiss and arsenical copper at Early Bronze Age Arisman, Iran. Journal of Archaeological Science 39, 1717-1727.

Rehren, Th., Leshtakov, P. Penkova, P. 2016. Reconstructing Chalcolithic copper smelting at Akladi chairi, Chernomoretz, Bulgaria. In: V. Nikolov, W. Schier (Eds), Der Schwarzmeerraum vom Neolithikum bis in die Früheisenzeit (6000-600 v.Chr.), Leidorf, Rahden, 205-214.

Schoer, B., Rehren, Th., 2007. The Composition of Glass and Associated Ceramics from Qantir, in: Pusch, E.B., Rehren, Th. (Eds.), Hochtemperatur-Technologie in der Ramses-Stadt: Rubinglas für den Pharao. Gerstenberg, 171-200.

487 